Jan Paweł II. Posługa myślenia, t. 2, red. ks. B. Kastelik, A. Krupka, ks. R. Woźniak, Kraków 2015, s. 195-211

(Studia nad Myślą Jana Pawła II, 17).

DOI: http://dx.doi.org/10.15633/9788374384933.11

Agnieszka Kurnik

\title{
JANA PAWŁA II TEOLOGIA HISTORII
}

Zakładając, że pragnę zaprezentować Czytelnikom zarys rozważań o „teologii historii" Karola Wojtyły - Jana Pawła II, wypada wstępnie zaznaczyć, iż Jan Paweł II w swych przemyśleniach starał się przede wszystkim o pogłębienie i wprowadzenie w życie kolegialnej refleksji Soboru Watykańskiego II, nie zaś o budowanie „prywatnej” koncepcji teologicznej. U źródeł refleksji papieskiej znajdujemy bowiem zasadnicze przesłanie, że „historia każdego człowieka, a przez człowieka dzieje wszystkich narodów niosą w sobie szczególny przekaz

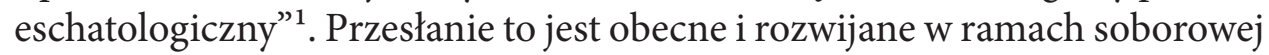
refleksji, w szczególności w dwóch, dla Jana Pawła II kluczowych konstytucjach: Konstytucji dogmatycznej o Kościele Lumen gentium i Konstytucji duszpasterskiej o Kościele w świecie współczesnym Gaudium et spes. Papież daje temu wyraz w całym swym nauczaniu, w syntetyczny sposób uzewnętrzniając tę prawdę w Pamięci i tożsamości, gdzie eksponuje historyczno-zbawczy wymiar każdego narodu, postrzegając dziejowe przeznaczenie wszystkich nacji jako wezwanie do wejścia w obszar zbawienia. Chodzi mu na tym tle przede wszystkim o pogłębiony namysł teologiczny nad stworzeniem, oparty na przesłaniu biblijnym i soborowych dokumentach, w świetle których możliwe jest dopiero rozpoznanie historycznych korzeni zła systemów totalitarnych, a także odkupieńczej i zbawczej „interwencji” Chrystusa w dzieje każdego człowieka, narodów - a ostatecznie całego świata ${ }^{2}$.

Ten rodzaj twórczej refleksji, powiązany z myślą soborową odsłania nam wielowymiarowy i powszechny aspekt koncepcji, przyjętej przez Vatica-

1 Jan Paweł II, Pamięć i tożsamość. Rozmowy na przełomie tysiącleci, Kraków 2005, s. 80 .

Tamże, szczególnie s. 78-92. 
num II - jednocześnie w znaczący sposób tę koncepcję rozwijając. „[...] Ten Papież - pisał Ojciec Święty Benedykt XVI - bardzo dobrze potrafił odróżnić osobiste opinie Karola Wojtyły od nauczania magisterskiego papieża. Jednocześnie wiedział, że te dwie rzeczy nie były różnorodne, ale odzwierciedlały jedną osobowość, czerpiącą z wiary Kościoła. Własne «ja» i swoją osobowość ukształtował przez «my» - i całkowicie oddał na służbę «my». W ten sposób nie sprowadził «my» do subiektywnego poziomu prywatnych opinii, ale po prostu ubogacił przez «ja». Sądzę, że takie stopienie «my» $\mathrm{z}$ «ja», które dojrzewało w życiu i refleksji nad wiarą, kształtowało w istotny sposób niezwykłość postaci Jana Pawła II. Takie połączenie pozwalało mu zachowywać się na tym świętym urzędzie $\mathrm{z}$ wielką swobodą i naturalnością: pozwalało mu być jako papieżowi całkowicie sobą, bez obaw o zbytnie przesunięcie tego urzędu w stronę subiektywizmu"3.

Sama refleksja teologiczna Karola Wojtyły i Jana Pawła II o historii powszechnej, a także historii Europy, w tym Polski jest co bardzo istotne, podobnie jak soborowa, oparta na przenikaniu się dwóch rzeczywistości - wiary i wiedzy. Jest zatem syntezą papieskiej wiedzy historycznej i doświadczenia uczestnictwa w wydarzeniach linearnie pojmowanego czasu, wzmocnionych wiarą własną i wiarą Kościoła powszechnego, a także refleksją Urzędu Nauczycielskiego Kościoła nad Pismem Świętym i przyjętymi oficjalnie dokumentami Vaticanum II. Tak czas posługiwania biskupa Wojtyły w Kościele krakowskim, jak pontyfikat Jana Pawła II - jak twierdzi ks. Andrzej Dobrzyński - były typowo soborowo nakierowane. Przypomnijmy, że bp Wojtyła uczestniczył w soborze „[...] od pierwszego do ostatniego dnia jego trwania, a więc od 11 października 1962 do 8 grudnia 1965 . Wziął udział w czterech sesjach, zabierał głos w auli soborowej, zgłaszał interwencje pisemne, pracował w komisji, redagującej konstytucję Gaudium et spes, współtworzył stanowisko Episkopatu Polski wobec dyskutowanych zagadnień, nawiązywał relacje z innymi biskupami i teologami”" . Sobór miał dlań przede wszystkim wymiar duchowy, co w wygłaszanych w archidiecezji krakowskiej homiliach wyraźnie zaznaczał. Częste spotkania z przedstawicielami innych nacji, bezpośrednie doświadczanie powszechności Kościoła rodziło przeświadczenie o konieczności przy-

3 Benedykt XVI (Joseph Ratzinger), Jedność misji i ducha Jana Pawła II, [w:] tegoż, Jan Paweł II. Mój umiłowany Poprzednik, Częstochowa 2007, s. 17-18.

$4 \quad$ A. Dobrzyński, Duszpasterska wizja Soboru Watykańskiego II abpa K. Wojtyły, [w:] K. Wojtyła, Odnowa Kościoła i świata. Refleksje soborowe, wybór i oprac. A. Dobrzyński, Kraków-Rzym 2011, s. 7. 
bliżenia soborowych treści wiernym archidiecezji krakowskiej. Rozważania archidiecezjalne, głoszone przed czterdziestu z górą laty, skupione wokół myśli soborowej miały na celu głębsze zaznajomienie wiernych i ludzi dobrej woli zarówno z założeniami tej myśli, jak i ze sposobami wdrażania jej w życie 5 . „Jan Paweł II ukazywał nauczanie Soboru Watykańskiego II jako fundament programów i projektów duszpasterskich. Podkreślał, że chodzi o «wcielenie nauki Vaticanum II w życie każdego człowieka i całego Kościoła»"6.

Obrady soboru, który w założeniach tematycznych miał przede wszystkim oświetlić i zadekretować prawdę o Kościele II połowy XX wieku i wymiarze zadań, które należy podjąć, by odnowa Kościoła i świata stała się faktem, zbiegały się w czasie z rozpoczęciem obchodów Millennium Chrztu Polski w $1966 \mathrm{roku}^{7}$. W jednym z listów do redaktora naczelnego „Tygodnika Powszechnego" Jerzego Turowicza abp Karol Wojtyła dzieli się swoimi przemyśleniami o zbliżającym się Millenium w kontekście Wielkiej Nowenny i wydarzeń soborowych ${ }^{8}$. Opatrzność zrządziła, że sam moment obchodzenia Millenium w Polsce zachodził już rok po zakończeniu Vaticanum II, a zatem w czasie, w którym, jak prognozował abp Wojtyła, założenia myśli soborowej zaczną być wdrażane w życie. Naświetla zatem Turowiczowi szczególny związek soboru z Wielką Nowenną, pokazując, jak w zakresie przegotowań do owej uroczystości partykularnej Kościoła w Polsce plan działań Kościoła powszechnego biegnie razem z planem Kościoła polskiego. Zarazem także stara się uzasadnić, jak wielu dodatkowych wartości dostarcza myśl Vaticanum II, gdy odnieść się do przeprowadzenia szczegółowej analizy samego faktu chrztu Polski i jego dalekosiężnych, tak historycznych, jak i pozahistorycznych skutków.

Abp Wojtyła już na samym wstępie wspomnianego listu sygnalizuje zasadniczą różnicę pomiędzy myśleniem w kategoriach czysto historycznych i kategoriach ewangelicznych. Gdyby bowiem zastosować miarę historyczną przyjęcia przez Polskę chrztu, należałoby powiedzieć, że w roku 966 na mapie

$5 \quad$ Zob. wspomniany w przypisie powyżej zbiór kazań i konferencji abpa Karola Wojtyły z archidiecezji krakowskiej (za lata 1962-1966) stanowiący pierwszą część cyklu publikacji okołosoborowych przyszłego papieża.

6 A. Dobrzyński, Duszpasterska..., dz. cyt., s. 13; por. Jan Paweł II, list Tertio millennio adveniente, 20.

7 Tamże, s. 9.

8 Przedrukowany list do redakcji „Tygodnika Powszechnego” z 2 maja 1965 roku, publikowany w 18 numerze tegoż pt. Aby Chrystus się nami posługiwał: K. Wojtyła, Millennium a sobór, [w:] tegoż, Odnowa..., dz. cyt., s. 267-271. 
historii Polski pojawił się, bądź, jak chce Wojtyła, „narodził” nowy byt - Kościół. Odwracając jednak porządek i przyjmując miarę ewangeliczną, musimy uznać, że to my - jako jednostki i jako wspólnota - w roku 966 niejako „narodziliśmy się" w Kościele i dla Kościoła. Ten sposób myślenia pokazuje nadrzędną i kongenialną wartość porządku nadprzyrodzonego, prezentując sakrament chrztu i głęboką interpretację jego sensu w myśli soborowej: „Chrzest bowiem - powiada Wojtyła - kryje w sobie tajemnicę narodzin z Boga i dla Boga. Jest to tajemnica łaski niewidzialnej, rzeczywistość porządku nadprzyrodzonego. Równocześnie jednak chrzest jest widzialnym znakiem, jest sakramentem Kościoła. Gdy Kościół udziela tego sakramentu, wówczas wprowadzając człowieka w życie Boże, wciąga go równocześnie w życie swoje. Uczestnictwo w życiu wewnętrznym Boga i członkostwo Kościoła idą ze sobą w parze. Dlatego też medytacja soborowej Konstytucji o Kościele bardzo pomaga w zrozumieniu w sposób teologiczny historycznego faktu sprzed tysiąca lat. Sobór przyszedł nam z tą Konstytucją (Lumen gentium - przyp. A. K.) jakby w samą porę"9.

Jak jednak przedstawia się, w wizji Jana Pawła II, opartej jednoznacznie na ustaleniach obu konstytucji rola Europy, w tym Polski, w procesie zbawienia i uświęcenia świata? Czy naród polski, a także inne narody Europy rozumieją swoją historyczną rolę $\mathrm{w}$ procesie zbawienia? W jaki sposób owa rola wiąże się z rzeczywistością Kościoła powszechnego? Czy i w jakim stopniu narody Europy i świata odpowiadają na kierowane do nich wezwanie Kościoła do pomnażania świętości, do której są przecież - w tworzących je osobach powszechnie powołane? Pytania te są tym bardziej zasadne, że znajdujemy się aktualnie u progu Roku Wiary ${ }^{10}$ i niejako w trakcie nowej ewangelizacji, koniecznej dla umocnienia w świecie współczesnym podstaw „cywilizacji miłości", budowanej na odkupieńczej ofierze Jezusa Chrystusa.

$\mathrm{Na}$ tym tle wypada rozpocząć od stwierdzenia, eksponowanego w powyższym liście, że w roku 966 w naszą historię weszła historia zbawienia, zarówno w porządku łaski - znaku niewidzialnego, jak i obecności Kościoła - znaku widzialnego, którego częścią jesteśmy. W myśl wcześniejszych stwierdzeń rzec można, że chrzest niejako „prześwietlił” i naznaczył historię narodu polskiego i innych narodów, z jednej strony uzdalniając je do działania ewangelizacyjnego, z drugiej zaś strony - stawiając przed olbrzymią odpowiedzialnością. Chrzest jest bowiem włączeniem w mistyczne Ciało Chrystusa, jest darem,

Tenże, Odnowa..., dz. cyt, s. 267-268.

10 Tekst wykładu był prezentowany publicznie 25 października 2012 roku. 
który domaga się odpowiedzi, a zarazem jest znakiem przynależności do Kościoła jako wspólnoty ludzi wierzących. Stąd od tej pory całą myśl historyczną należy postrzegać jako „prześwietloną” przez chrzest, nadający owym wydarzeniom niezwykłe piętno. W porządku nadprzyrodzonym jesteśmy, zarówno, jako jednostki, jak i jako narody niejako „ludem mesjańskim”, włodarzami powierzonej nam ziemi, powołanymi do naśladowania Chrystusa i upodabniania się do Niego.

Problem mesjanizmu u Wojtyły był rozpatrywany m.in. w kategoriach filozoficzno-historycznych przez środowisko „Pressji” na gruncie polskim ${ }^{11}$, ale nazywając Jana Pawła II przedostatnim (po nim już tylko, jak chce tego Paweł Rojek, Jerzy Braun $)^{12}$ polskim mesjanistą, nie zwrócono chyba uwagi na charakter owego mesjanizmu, a konkretnie - na pogłębione rozumienie pojęcia: „Ludu Bożego (ludu mesjańskiego)”, istniejącego przecież w dokumentach soborowych jako nowa forma "narodu wybranego". O ile bowiem zainteresowanie Wojtyły polskim mesjanizmem (a raczej mesjanizmami), przejawiające się przede wszystkim w dramaturgii młodzieńczej, przypisywać należy zacięciu polonistycznemu, romantycznym lekturom i zainteresowaniom aktorskim (vide: romantyczny repertuar Teatru Rapsodycznego Mieczysława Kotlarczyka), a także (w okresie studiów polonistycznych na UJ) uczestnictwu w wykładach i seminariach prof. Stanisława Pigonia, wybitnego znawcy epoki - o tyle ustalenia soboru są w tym przypadku sprawą absolutnie podstawową i konkluzywną. Gdyby tak nie było, Wojtyła nie podkreślałby roli Ludu Bożego w historii zbawienia w liście do Turowicza, w którym nie tylko ten rodzaj myślenia wyjawia, ale stara się te właśnie zagadnienia zaprezentować jako stojące w centrum całej problematyki milenijnej.

Odrębne miejsce w ramach tej refleksji zajmuje zarówno Polska, jak i Europa, oraz Kościół polski, którego specyficzny wkład w historię Kościoła powszechnego Jan Paweł II, ale i Karol Wojtyła bardzo często i znacząco podkreśla. Wiemy doskonale, że całe doświadczenie „ziemi trudnej jedności”, „dalekiego kraju” przeniósł na grunt europejski i światowy tylko dlatego, że od samego początku więzi z jego ojczystą, polską ziemią i rodakami były serdeczne i głębokie. Wychowany w duchu patriotycznym w wadowickim Gimnazjum im. Marcina Wadowity już w najwcześniejszych latach życia

11 Zob. „Pressje” 2012, teka 28: Powrót mesjanizmu. Tu m.in. interesujący tekst K. Mazura: Jerzy Braun i mesjanizm Jana Pawła II, wskazujący na możliwość inspiracji Karola Wojtyły mesjanistyczną myślą Jerzego Brauna.

12 Zob. P. Rojek, Mesjanizm integralny, „Pressje” 2012, teka 28, s. 25. 
styka się z podstawową refleksją teologiczną, która ukształtuje zrąb jego życia kapłańskiego, biskupiego i papieskiego. Myślę tu o zegarze słonecznym, widocznym z okien rodzinnego domu i słowach: „Czas ucieka - wieczność czeka”. W perspektywie wieczności czas linearny i przemijalność życia doczesnego nie stają się dlań, by tak rzec - centralnym sposobem myślenia o naturze stworzonego świata, a tym samym także więzi międzyludzkich. W perspektywie wieczności życie niebieskie jest bowiem kontynuacją ziemskiego, a czas linearny jest niejako wpisany w czas kolisty, czas liturgiczny roku kościelnego, w obrębie którego już teraz - budując Boże królestwo - przygotowujemy się na spotkanie z Wiecznością.

Przemawiając tuż po inauguracji pontyfikatu do rodaków przybyłych do Rzymu na podniosłe uroczystości, prosił przede wszystkim o to, by trwano z nim na modlitwie. Wiedział, że zrodzony z chrześcijańskiej wiary i tradycji naród, rodacy i on to system "naczyń połączonych”, ciąg nieustannej modlitewnej łączności. Wierzył także, że ich modlitwa słów i serc wspomoże siły ducha i wyprosi mu u Boga liczne łaski - u progu podjęcia nowych, ważnych zadań i wyzwań. I odwrotnie - jego modlitwa za naród uzdolni ów naród do wielkich i ważnych z perspektywy wiary czynów. Jest tak, jakby - podobnie, jak działo się to w czasie Soboru Watykańskiego II - włączał cały polski Kościół i naród w „sztafetę modlitewnych pokoleń”. Prosząc o modlitwę, a zarazem czując wsparcie modlitewne, wprowadzał niejako poprzez własne, modlitewne zaangażowanie każde jednostkowe doświadczenie ludzkie, jak i doświadczenie historii narodu polskiego w ciąg kierowanych do Boga próśb, błagań i - nade wszystko - dziękczynień. Tym samym kontynuował rozpoczęte w archidiecezji krakowskiej budowanie „mostów” między teraźniejszością ziemską a przyszłością wieczną - będące przecież zalążkiem Norwidowego rozumienia człowieczeństwa. Powracając do słów wypowiedzianych w Kalwarii Zebrzydowskiej w czerwcu 1979 roku (prośba o modlitwę za jego życia i po śmierci $)^{13}$ podczas ostatniej pielgrzymki w Kalwarii Zebrzydowskiej zamyka, jak klamrą, czas ziemski owego „budowania”, z drugiej strony jednak otwiera je na wieczność. Dziś, gdy dostępuje chwały ołtarzy jako Błogosławiony, a jednocześnie, gdy dzień Jego kanonizacji jest tak bardzo bliski - widać wyraźnie, że wszystko, co wówczas czynił, było głęboko przemyślane, ale i realizowane za natchnieniem Ducha Świętego, którego rolę w trakcie obrad soboru jedno-

13 Zob. Przemówienie Ojca Świętego w Kalwarii Zebrzydowskiej, [w:] W pielgrzymce do ojczystej ziemi. Jan Paweł II w Polsce 2 VI - 10 VI 1979, pod red. Z. Modzelewskiego SAC, J. Sadzika SAC, D. Szumskiej, Paryż 1980, s. 156-161. 
znacznie podkreślał. Co więcej, było także - jak widać - głęboko Norwidowe. To Norwid, wedle Jana Pawła II ,jeden z prekursorów Vaticanum II" pisał bowiem o człowieczeństwie jako „kapłaństwie bezwiednym i niedojrzałym” oraz o „budowaniu mostów pomiędzy Bogiem a człowiekiem - i wszystkich z Bogiem" ${ }^{14}$.

Jan Paweł II zbudował tych mostów bardzo wiele i nadał im trwały kształt. Co więcej, nadal je buduje, gdyż - tak jak w wypadku siostry Faustyny jego misja $\mathrm{z}$ racji świętych obcowania tylko zmieniła charakter, ale wcale nie dobiegła końca. Ale i naród polski, współpomagając mu modlitewnie w tym zakresie, sam także realizował i nadal realizuje (być może „bezwiednie i nieświadomie") Norwidową - a później i wynikającą ze wskazań Soboru Watykańskiego II - ideę powszechnego kapłaństwa osób. Co więcej, naród, wspierając papieża swoją modlitwą, był i jest tym samym niejako „rzecznikiem" swego czasu.

Nietrudno jednak zauważyć, że obok doświadczenia Kościoła powszechnego w centrum ówczesnych zainteresowań papieża i jego rodaków stał trudny problem relacji Kościół - państwo w komunistycznej Polsce, a także odnowa duchowa i moralna Narodu, znajdująca swe odzwierciedlenie w latach polskiej Wielkiej Nowenny. Efektem jej zainicjowania (vide: uroczystości millenijne) była, wynikająca bezpośrednio z owoców pierwszej pielgrzymki idea „Solidarności”, owocująca walką o prawa człowieka oparte na poszanowaniu osoby ludzkiej. „Solidarność” jako wspólnota od samego początku odwołująca się do polskiego dziedzictwa duchowego, religijnego i narodowego, wyraźnie przyznająca się do ścisłej łączności z biskupem Rzymu - w perspektywie moralnej odnowy wyrastała jednak także, o czym się chyba wcale nie wspomina, z podstawowych założeń Vaticanum II, przenoszonych na polski grunt niestrudzenie przez Prymasa Tysiąclecia i kard. Karola Wojtyłę. U jej podłoża legła także, wynikająca $\mathrm{z}$ istoty nauczania papieskiego specyficzna, a niezmiernie istotna dla zachowania ciągłości historycznej „hermeneutyka kultury narodowej” - również zbliżona do Norwidowej, jak sugerował Jan Andrzej Kłoczowski: „Można odrzucać naród jako więź mało istotną, przypadkową. Można z narodu uczynić byt nadrzędny, jeżeli nie najwyższy i jemu podporządkować wszystkie inne wartości. I można rozumieć naród personalistycznie. Do młodzieży na Skałce w 1979 roku powiedział Papież: «Wy macie przenieść ku przyszłości to olbrzymie doświadczenie dziejów,

14 Jan Paweł II, Audiencja papieska dla przedstawicieli Instytutu Dziedzictwa Narodowego. Z poezji Norwida emanuje światło. „L’Osservatore Romano” 2001 nr 9, s. 54. 
któremu na imię Polska». Polska to nie byt oderwany, abstrakcyjny, to suma doświadczeń ludzi, «każdego» Polaka.

Ta wizja mieści się konsekwentnie w antropologii Jana Pawła II wyrażonej już w encyklice Redemptor hominis: «Nie chodzi o człowieka «abstrakcyjnego», ale rzeczywistego, o człowieka «konkretnego», «historycznego». Chodzi o człowieka 'każdego' - każdy bowiem jest ogarnięty Tajemnicą Odkupienia, z każdym Chrystus w tej tajemnicy raz na zawsze się zjednoczył» (n. 13). Nie chodzi więc także o «Polaka abstrakcyjnego» (ktoś by powiedział: «prawdziwego»), ani o abstrakcyjną Polskę, ważny jest człowiek, myślany indywidualnie, w swej konkretnej niepowtarzalności, ale bynajmniej nie indywidualistycznie. Człowiek uczestniczy we wspólnocie, w zbiorowej wymianie doświadczeń ludzkich, uczestniczy w życiu innych. Jedną z postaci takiego doświadczenia wspólnotowego jest byt narodowy. Nie można go pominąć w myśleniu o człowieku, jest on jednym z najistotniejszych czynników jego wychowania i kształcenia" ${ }^{2}$. Czy nie należy zatem postrzegać powstania "Solidarności” jako skutku prośby o jedność narodu z papieżem, czerpiącym z myśli sobo$\mathrm{ru}$ - wyrażonej u progu inauguracji pontyfikatu właśnie w owej encyklice? ${ }^{16}$. Ostatecznie solidarność i odnowa moralna narodu ${ }^{17}$ jest syntezą pragnień Ojca Świętego i wspólnoty Polaków. Jest to tym bardziej uprawnione, że do takiego rozumienia ojczystych dziejów w wyżej wspomnianym liście do Turowicza zachęca nas abp Wojtyła: „Możemy odczytywać jeden po drugim rozdziały Konstytucji, przykładając je z kolei do naszego tysiąclecia jak miarę i sprawdzian. Studium Konstytucji o Kościele może się stawać w ten sposób rozpamiętywaniem tysiąclecia, rozpamiętywanie tysiąclecia może przechodzić w studium konstytucji. Skojarzenia historyczne nabiorą wtedy nowych znaczeń, znaczenia zaś teologiczne osadzą się w biegu wydarzeń. Ewangelizacja, hierarchia, kapłaństwo, zakony, święci, męczennicy i wyznawcy, a równocześnie grzesznicy - wielcy i mali - upadający i dźwigający się, owszem, dźwigający innych. Historia zbawienia utożsamia się z dziejami konkretnych ludzi. Jest to równocześnie historia rodzin zawiązywanych w sakramentalnym małżeństwie, przekazujących życie nowym pokoleniom, a wraz z życiem wiarę

15 J. A. Kłoczowski OP, Pielgrzymowanie po Polsce żywa katecheza, [w:] Jan Paweł II, Musicie od siebie wymagać, Poznań 1984, s. 16-17.

16 Encyklika Redemptor hominis sygnowana została dnia 4 marca 1979 roku, w pierwszą niedzielę Wielkiego Postu, w pierwszym roku nowego pontyfikatu, tuż przed odwiedzinami w ojczyźnie. Zob. Jan Paweł II, Redemptor hominis, [w:] Encykliki Ojca Świętego bł. Jana Pawła II. Kompletne wydanie. Pamiątka beatyfikacji, Kraków 2011, s. 5-48.

17 Zob. J. Tischner, Etyka solidarności, Kraków 1981. 
i kulturę" ${ }^{18}$. Czy pierwsza pielgrzymka nie obudziła w nas pragnienia głębokiej przemiany serc i sumień narodowych w duchu Ewangelii i Dekalogu? Czy może być zaskoczeniem, że słowa „nowa ewangelizacja” padają po raz pierwszy podczas pamiętnej pierwszej pielgrzymki do Polski nie gdzie indziej, lecz w Nowej Hucie-Mogile, w Sanktuarium Cudownego Pana Jezusa? ${ }^{19}$

Jan Paweł II jest zatem, zwłaszcza w wezwaniu Ducha Świętego z prośbą o „odnowę oblicza ziemi, tej ziemi” głęboko „mesjaniczny”, zarówno w znaczeniu biblijnym i soborowym, jak i romantycznym - polskim. Czy można oddzielić historię narodu polskiego od historii polskiego Kościoła?

Karol Wojtyła - Jan Paweł II nigdy tego nie czynił. W juweniliach dramatycznych wyraźnie łączył wizję mesjanistyczną Polski z wizją „przedmurza chrześcijaństwa" (Hiob, Jeremiasz). Nigdy jednak, nawet w czasach młodzieńczych mesjanizm jego nie ograniczał się wyłącznie do ziemskiego, partykularnego „tu i teraz”. Zawsze wychylał się w stronę oczekiwania Wieczności, jako rzeczywistości niepoznanej, a wytęsknionej.

Więź Kościoła z narodem, uwarunkowana historycznie, w duchu „Solidarności" znalazła swój stanowczy wyraz. Prześladowania, które stały się nieuchronnie udziałem "Solidarności” po wprowadzeniu stanu wojennego, zaowocowały męczeńską śmiercią błogosławionego ks. Jerzego Popiełuszki niezłomnego Kapelana „Solidarności”. Na jego grobie podczas pielgrzymki w roku 1987 modlił się Jan Paweł II $^{20}$. Słowa św. Pawła, brzmiące w ustach ks. Jerzego jak testament: „nie daj się zwyciężyć złu, ale zło dobrem zwyciężaj" były echem Chrystusowej męki, śmierci i zmartwychwstania. Umacniały ziemską wspólnotę polskiego narodu, przyczyniając się do ugruntowania duchowej łączności tegoż narodu z Bogiem, który jest przecież Panem historii. Tym samym „omadlając” ofiary wojen, wspominając nieustająco los Polski i podnosząc historyczną sprawę polską na arenie międzynarodowej, Jan Pa-

\footnotetext{
18 K. Wojtyła, Odnowa..., dz. cyt.., s. 268.
}

19 Zob. Jan Paweł II, Homilia wygłoszona w Sanktuarium Świętego Krzyża w Mogile, [w:] W pielgrzymce do ojczystej ziemi, dz. cyt., s. 205-212.

20 „Wśród pielgrzymów, którzy przybyli do grobu ks. Jerzego Popiełuszki, był też tak bardzo podziwiany przez kapelana «Solidarności» Ojciec Święty Jan Paweł II. 14 czerwca 1987 r. w bramie świątyni powitał go bardzo już wtedy schorowany ks. Teofil Bogucki [...]. Papież najpierw długo modlił się w kościele, a potem udał się do grobu kapelana „Solidarności”. Złożył wiązankę biało-czerwonych róż. Obejmując ramionami kamienną płytę grobową w kształcie krzyża, modlił się, a potem z szacunkiem ją ucałował”. Zob. J. Sosnowska, Prawy i sprawiedliwy. Życie i męczeństwo Błogosławionego Księdza Jerzego Popiełuszki, Kraków 2010, s. 42 . 
weł II nie tylko przyczyniał się do głębszego rozumienia jej natury w świecie, ale w pierwszym rzędzie powierzał wszystkie te sprawy Sercu Maryi i Sercu Jezusa, wypełniając w ten sposób testament Vaticanum II.

Wracając do mesjanizmu: można domniemywać, że dzięki wspomnianym wyżej wykładom i seminariom polonistycznym zetknął się tak z odmianami mesjanizmu Augusta Cieszkowskiego i Józefa Hoene-Wrońskiego, jak i z wizjami, których rzecznikami byli: Andrzej Towiański, Adam Mickiewicz, Juliusz Słowacki i Zygmunt Krasiński. O ile w przypadku koncepcji romantycznych trzech ostatnich nazwisk ich znajomość nie ulega żadnej wątpliwości (fakt ten potwierdzają jednoznacznie papieskie uwagi i cytowania, a także katakumbowy repertuar Teatru Rapsodycznego Kotlarczyka), o tyle bezpośredniego potwierdzenia znajomości koncepcji np. Towiańskiego zarówno w pismach Wojtyły, jak i w pismach Jana Pawła II brak. Wypada jednak stwierdzić, że idee Towiańskiego (m.in. określenie Żydów w rzymskiej synagodze mianem „starszych braci w wierze”) dotarły do Wojtyły najpewniej za pośrednictwem pism Mickiewicza (Skład zasad, 1848). Wobec mesjanizmu, widzianego z perspektywy heroicznego czynu, nie mógł jednak Wojtyła pozostać obojętny. Echo wybrania i powołania Polski jako narodu i Kościoła brzmi szczególnie znacząco podczas rozważań o własnym powołaniu na Stolicę Piotrową i w perspektywie rzekomego „powrotu” Polski (przyjmowanej do Unii Europejskiej) do Europy:

Kiedy wieczorem, 16 października 1978 roku stanąłem po raz pierwszy na balkonie Bazyliki św. Piotra, aby pozdrowić rzymian i pielgrzymów, zgromadzonych na placu w oczekiwaniu na wyniki konklawe, powiedziałem, że przychodzę „z dalekiego kraju”. W gruncie rzeczy ta odległość w sensie geograficznym nie była tak wielka. Samoloty pokonywały ją zaledwie w dwie godziny. Mówiąc o dalekości, miałem na myśli istniejącą jeszcze w tamtym momencie „żelazną kurtynę”. Papież, który przychodził spoza „żelaznej kurtyny”, w prawdziwym sensie tego słowa przychodził „z daleka”, chociaż w rzeczywistości przychodził z samego centrum Europy. Przecież geograficznie centrum Europy znajduje się właśnie na terenie Polski.

W latach istnienia „żelaznej kurtyny” zapomniano o Europie Środkowej. Stosowano dość mechanicznie podział na Zachód i Wschód, uznając Berlin, stolicę Niemiec, za miasto - symbol, przynależące jedną swą częścią do Niemiec Federalnych, a drugą do Niemieckiej Republiki Demokratycznej. W rzeczywistości ten podział był całkowicie sztuczny. Służył celom politycznym i militarnym. Wyznaczał granice dwóch bloków, ale nie liczył się z historią ludów. Polakom trudno było przyjąć do wiadomości, że należą do Wschodu, zwłaszcza biorąc pod uwagę fakt, iż właśnie w tych latach granice Polski 
zostały przesunięte na Zachód. [...] Z tego punktu widzenia powołanie papieża z Polski, z Krakowa, mogło mieć wymowę niejako symboliczną. Nie było to jedynie powołanie konkretnego człowieka, ale całego Kościoła, z którym był on związany od urodzenia; pośrednio było to także powołanie narodu, do którego należał. Zdaje mi się, że tę sprawę szczególnie jasno widział i wyraził Kardynał Stefan Wyszyński. Osobiście byłem zawsze przekonany, że wybór Polaka na papieża tłumaczył się tym, czego Prymas Tysiąclecia wraz z Episkopatem i Kościołem polskim potrafili dokonać w warunkach ograniczeń, ucisku i prześladowań, jakim byli poddani w tamtych trudnych latach ${ }^{21}$.

Ten właśnie człowiek wiary heroicznej, internowany i prześladowany, w swoim testamencie, sporządzonym 15 sierpnia 1969 roku na Jasnej Górze powiadał:

[...] Zawsze budowały mnie przedziwny szacunek i miłość, z jaką odnosili się Papieże do Kościoła w Polsce, do Biskupów, kapłanów - i do mnie. Wiem, że zawsze ufali Kościołowi Polskiemu, chociaż nie mogli niektórych naszych postulatów spełnić. Piszę to dlatego, bo wiem, że w Polsce istnieje cała biblioteka politycznych publikacji, które zniekształcają właściwy obraz rzeczywistości.

Kościołowi w Polsce służyłem według najlepszego mojego zrozumienia jego sytuacji i potrzeb. Chciałem obronić Kościół przed zaprogramowaną ateizacją i przed „fałszywymi braćmi", którzy na własną rękę uprawiali nieuczciwą politykę kościelną w dziedzinie państwowej, przed nienawiścią społeczną doktrynalnie zachwalaną, przed rozwiązłością, której odgórnie patronowano. Uważam sobie za łaskę, że mogłem - z pomocą Episkopatu Polski - przygotować Naród przez Wielką Nowennę, Śluby Jasnogórskie, Akt Oddania Narodu Bogurodzicy w macierzyńską niewolę Miłości i Społeczną Krucjatę Miłości - na nowe Millennium. Gorąco pragnę, by Naród Polski pozostał wierny tym zobowiązaniom ${ }^{22}$.

Pragnienia Prymasa Wyszyńskiego podzielał także kard. Wojtyła. Szczególną jego cechą było personalistyczne traktowanie tych, których na swej drodze spotykał. Przyjmował z sercem wszystkich, nigdy nie różnicował rodaków ostentacyjnie na „inteligentów” i „ludzi prostych”. Wszyscy oni byli dla niego: „mesjańskim Ludem Bożym”, o wielu powołaniach i charyzmatach. Mimo wielokrotnych prób skłócania kard. Wyszyńskiego z kard. Wojtyłą,

\footnotetext{
21 Jan Paweł II, Pamięć i tożsamość, dz. cyt., s. 146-147.

22 Testament warszawski Prymasa Polski, [w:] B. Piasecki, Ostatnie dni Prymasa Ty-
} siąclecia, Rzym 1982, s. 170-171. 
prób ustawiania ich na przeciwległych biegunach katolicyzmów: „ludowego” i „intelektualnego”, Jan Paweł II nigdy nie dał się zwieść pochlebcom i „krytykantom" linii, przyjętej przez posługę kard. Stefana Wyszyńskiego, Prymasa Tysiąclecia. Ich wzajemna więź uzewnętrznia się najlepiej w geście homagium, składanego podczas inauguracji pontyfikatu następcy Piotra, a uwiecznionego następnie w postaci pomnika autorstwa Jerzego Jarnuszkiewicza na dziedzińcu Katolickiego Uniwersytetu Lubelskiego. Tu słowa są naprawdę niepotrzebne.

W okresie soborowym zatem myśl Wojtyły, czy to w zakresie twórczości literackiej, czy homiletyki stale krąży wokół relacji narodu polskiego do Kościoła i perspektywy obecności wymiaru teologicznego w historii narodu polskiego i innych narodów. Konkluzja Wojtyły - poety brzmi następująco: gdyby nie wymiar chrztu (obrzędu i wszczepienia w pień drzewa życia), historia poszczególnych ludów i narodów byłaby jedynie stałą zgodą na śmierć. Postrzegana jedynie jako czas przemijania pokoleń, pozbawiona wymiaru odkupienia i zbawienia historia jest bowiem jedynie pustą sekwencją doczesnych wydarzeń, świadectwem linearnego, horyzontalnego bytowania ku śmierci. Dopiero chęć wyjścia poza historię w doświadczeniu przyjęcia chrztu transcenduje naszą miłość ku ziemi, na której żyjemy, wnosząc w nią prawdę wydarzeń, rozgrywających się w Ziemi Świętej. Jest jednocześnie sygnałem wyjścia poza czas, przestrzeń i śmierć i włączenia historii naszych dziejów w obręb czasu sakralnego. Włączenie to jest skutkiem właściwego rozpoznania relacji „przygodności bytowej” człowieka wobec Boga, znajdującej swój wyraz w trzech pierwszych rozdziałach Księgi Rodzaju.

Akt przyjęcia chrztu przez Mieszka I, do którego Wojtyła nawiązuje, jest bowiem aktem potwierdzenia podwójnego związku ziemi z człowiekiem (Wigilia wielkanocna 1966) ${ }^{23}$ : tak zakorzenienia w ziemi ojczystej jako darze i zadaniu, jak i ugruntowania w Ziemi Świętej, będącej znakiem życia wiecznego, miejscem narodzin i zbawczej śmierci krzyżowej Odkupiciela, Boga-Człowieka (Wędrówka do miejsc świętych) ${ }^{24}$. Wojtyła widzi zarówno miłość Polaków do ziemi własnej, jak i miłość każdego innego narodu do ziemi ojczystej w perspektywie wychodzenia poza „śmiertelne” bytowanie w linearnej historii. Zatem naturalna miłość ku ziemi ojczystej jest wyjściem poza śmierć, dotknięciem miłości Boga Ojca do stworzenia (jesteśmy wszak stworzeni na obraz i podobieństwo Boże i stworzeni z miłości!), ponownym

23 K. Wojtyła, Wigilia wielkanocna 1966, [w:] tegoż, Poezje i dramaty, Kraków 2001, s. $88-99$.

24 Tenże, Wędrówka do miejsc świętych, [w:] tegoż, Poezje i dramaty, dz. cyt., s. 82-87. 
zanurzeniem każdego z nas w ziemi świętej, miejscu, które kieruje naszą uwagę zarówno ku narodzinom Chrystusa, jak i zbawczemu i odkupieńczemu aktowi Chrystusowego człowieczeństwa i boskości. Tym samym: tysiąc, i każda inna liczba lat istnienia chrześcijaństwa staje się w tej perspektywie - tak dla narodów, jak i dla każdego pojedynczego człowieka i całej ziemi jedną nocą, wieczną Wigilią, czasem eschatologicznym: oczekiwaniem na ponowne przyjście Chrystusa w chwale.

Ów podwójny akt miłości - do ziemi i Kościoła powszechnego włącza nas w sztafetę pokoleń świata, świadomie przeżywających miłość Boga i bliźniego oraz obcowanie świętych we wszystkich jego wymiarach i przejawach: tu, na ziemi - w czynnym trwaniu w nieustannym, adwentowym i wigilijnym oczekiwaniu na ponowne przyjście Zbawiciela. Tylko w tej perspektywie możliwe są owocujące kultem: męczeństwo św. Stanisława, patrona ładu moralnego w Ojczyźnie (Stanisław) ${ }^{25}$, męczeństwo świętego Maksymiliana Kolbe, oddającego życie za współwięźnia w bunkrze głodowym Auschwitz - niemieckiego obozu koncentracyjnego, heroiczne świadectwo i śmierć błogosławionego ks. Jerzego, a nareszcie - Boża logika „prowadzenia kuli” podczas zamachu na samego Jana Pawła II na placu Świętego Piotra 13 maja 1981 roku. To zresztą tylko przykłady „darów” Polski dla świata, wzorców, którymi polski Kościół męczeński obdarował święty Kościół powszechny. Jest ich znacznie więcej. Każdy z nich to przykład więzi ziemi ojczystej z ziemią świętą i z niebem.

Czy teza o wybraniu i powołaniu narodu polskiego, wyrosłego w symbiozie z Kościołem katolickim, ma zatem rację bytu - w konfrontacji z wyborem papieża Polaka i słowami, które on sam wypowiada u kresu swej ziemskiej wędrówki? To w Pamięci i tożsamości powie o szczególnym wybraniu polskiego narodu i Kościoła - jak uzasadnia następnie całym swym pontyfikatem - nie do panowania, ale do służby - przez wyrok pamiętnego konklawe. Czy w wyborze imion Jana Pawła II nie ma czegoś, co jednoznacznie wskazywałoby na aspekt ważnej roli Polski w Kościele powszechnym? Dokładnie przed stu laty odwiedził nas przyszły Papież Jan XXIII, odprawiając mszę świętą w katedrze wawelskiej, przed Czarnym Krzyżem innej świętej, ogłoszonej przez Jana Pawła II - królowej Jadwigi. 25 grudnia 1962 roku w homilii wygłoszonej w katedrze wawelskiej abp Wojtyła powiada: „Będąc tutaj, jakże miło wspomnieć, kiedy zaraz po przybyciu do Rzymu Ojciec Święty Jan XXIII, zaprosił nas, polskich biskupów, na audiencję, to z taką wnikliwością i jakimś rozczuleniem wspomniał Kraków i tę katedralną bazylikę na Wawelu. Bo jak

25 Tenże, Stanisław, [w:] tegoż, Poezje i dramaty, dz. cyt., s. 118-121. 
już na pewno wiecie $\mathrm{z}$ informacji prasowych i radiowych, przed pięćdziesięciu laty, w 1912 roku, odprawiał Mszę świętą na Wawelu. Kiedy Kapituła Metropolitalna, wzruszona tą pamięcią Ojca Świętego, zwróciła się do niego z zapytaniem, czy mógłby wskazać ołtarz, przed którym wówczas, 17 września 1912 roku, odprawiał tę Mszę świętą, Ojciec Święty własnoręcznie na tym adresie Kapituły napisał tak: «Kiedy wychodzę z zakrystii, mam przed sobą sarkofag królewski [...] Kieruję się na lewo, tam jest ołtarz Krzyża świętego. To był dzień 17 września, kiedy Kościół wspomina stygmaty św. Franciszka. Przed tym ołtarzem Ukrzyżowanego odprawiałem». Wiemy wszyscy, który to ołtarz - krzyż wawelski, czarny krzyż królowej naszej, Jadwigi. Ile nam to wszystko mówi? Ile nam mówi ta pamięć po pięćdziesięciu latach, ile mówi o nim do nas, o tej katedrze św. Stanisława, która tak szczególnie została zapamiętana przez Ojca Świętego"26.

I z tegoż Krakowa, ze Stolicy Świętego Stanisława, następuje powołanie kard. Karola Wojtyły na Stolicę Swiętego Piotra. Czy może to być przypadek?

Z kolei imię Pawła nawiązuje bezpośrednio do postaci Pawła VI, papieża, zamykającego klamrą doświadczenie Vaticanum II. A zarazem - ofiarowującego dla Kościoła, który powstał około kilometra od miejsca walki o krzyż Arki Pana - kamień z grobu Apostoła Piotra. To tu, w konsekrowanym przez kard. Wojtyłę kościele wyrasta bastion „Solidarności”. Czy to doświadczenie parafii, błogosławionej przez papieża Pawła VI i konsekrowanej przez kard. Wojtyłę nie wpisuje się w ciąg wydarzeń wyraźnie włączających polską historię w obręb czasu sakralnego? Czy potrzeba modlitwy u strajkujących, internowanych w czasie stanu wojennego, potrzeba łączności z Bogiem, wyrażana poprzez pieśń Ludu Bożego: „My chcemy Boga...”, „Boże, coś Polskę...” nie staje się bezpośrednio częścią doświadczenia Kościoła powszechnego? Czy nie wyraża pragnienia głębszej przemiany ziemi - danej i zadanej? Czy zatem naród, rozumiany jako wspólnota duchowa i kulturowa, można wykorzenić, oderwać go od pierwotnej ziemi - Matki i Kościoła? Czy naród może sam pragnąć tego wykorzenienia?

Nie, nie jest, i nie może być zatem przypadkiem, że słowa o nowej ewangelizacji pojawiają się po raz pierwszy w Nowej Hucie, 9 czerwca 1979 roku, w mieście bez Boga, które heroicznie broniąc swych praw do krzyża, znalazło w osobie abp. Wojtyły wielkiego orędownika. Tu dał się słyszeć głos Narodu, który upomniał się o swoje podstawowe prawa - prawo do wolności sumie-

26 Tenże, Misją Vaticanum II jest przybliżenie ludziom zbawienia, [w:] tegoż, Odnowa..., dz. cyt., s. 40 . 
nia i wyznania, prawo, będące $\mathrm{w}$ wyniku masowej ateizacji i kolektywizacji przypadającej na lata PRL-u wielokrotnie łamane, lekceważone i gwałcone. „Dzieje Nowej Huty są także napisane poprzez krzyż - naprzód poprzez ten stary, mogilski, odziedziczony tutaj po stuleciach - a potem poprzez inny, nowy... który postawiono niedaleko stąd. [...] Otrzymaliśmy znak, że na progu nowego tysiąclecia - w te nowe czasy i nowe warunki wchodzi na nowo Ewangelia. Że rozpoczęła się nowa ewangelizacja, jak gdyby druga, a przecież ta sama, co pierwsza. Krzyż trwa, choć zmienia się świat"27. Wydarzenia internowania Prymasa Polski, obrony krzyża w Nowej Hucie i wiele, wiele innych, wpisywały się w ciąg dążeń niepodległościowych narodu, a tym samym prawa do wolności publicznego dawania świadectwa. Czy dramat narodowej historii nie jest częścią polskiego doświadczenia, przeniesionego bezpośrednio do Watykanu?

Czy nie wyrastają z polskich doświadczeń przesiąknięte duchem Gaudium et spes encykliki papieskie? Czy Jan Paweł II nie uczynił ich częścią doświadczenia świata? I czy nie jest swoistym „chichotem historii” fakt lansowania w przestrzeni publicznej nieustannie powtarzanej tezy o konieczności „powrotu Polski do Europy"?

Jak zatem należy spojrzeć na te dwie rzeczywistości - Polski i Europy? Polska, jako się rzekło, była w Europie od zawsze. Krzywdzące wobec Polski opowieści o „doganianiu Europy” bądź „powrocie do Europy” wiązały się z porządkiem pojałtańskim i dawnymi podziałami politycznymi starego kontynentu na strefy wpływów. Ten sam klucz zastosowano bezrefleksyjnie wobec Polski, która wielokrotnie płacąc daninę krwi, współtworzyła od zawsze obraz europejskiego kontynentu, a w strefie wpływów sowieckich znalazła się w sposób wysoce niezasłużony.

Europa Zachodnia nie rozumiała - i nadal nie rozumie do końca - specyfiki historycznej ewolucji narodowej, której uczestnikami stali się Polacy. Trzeba bowiem zaznaczyć raz jeszcze, że data chrztu jest dla Jana Pawła II tożsama z datą określenia historycznej tożsamości narodu. Wcześniejszy etap, etap plemienny, Jan Paweł II postrzega przedtożsamościowo. Gdy Polska Piastów jest przez Jana Pawła II określana jako etnicznie „czysta” (w okresie, jak to określa Jan Paweł II, „zrastania się plemion”), Polska Jagiellonów jest wieloetniczna, wielokulturowa i różnorodna religijnie. Te dwa przeciwstawne doświadczenia, opisane zarówno w Pamięci i tożsamości, jak i w poemacie Myśląc ojczyzna

${ }^{27}$ Homilia Ojca Świętego wygłoszona w Sanktuarium Świętego Krzyża w Mogile, [w:] W pielgrzymce do ojczystej ziemi..., dz. cyt., s. 206. 
przez cały czas naznaczają specyfikę naszej tożsamości. Z tej racji nie rozumie się także do końca specyfiki polskiego patriotyzmu. Czy bowiem można być Żydem i jednocześnie polskim patriotą? Jak najbardziej. Takimi byli koledzy Karola Wojtyły z wadowickiego gimnazjum, co wielokrotnie sam podkreślał i starał się pokazywać światu, choćby poprzez przybliżanie sylwetki swego przyjaciela - Jerzego Klugera. Takim był także Żyd Jankiel - postać literacka, przedstawiona przez Mickiewicza w epopei narodowej Pan Tadeusz. To także część polskiego, zbiorowego doświadczenia, które z niezrozumiałych powodów znika obecnie z gimnazjalnego kanonu lektur.

Mówiąc o Europie, w Pamięci i tożsamości Jan Paweł II w pierwszym rzędzie przypomina rolę ewangelizacji kontynentu. Jak zaznacza, tak naprawdę ewangelizacja jest tym, co Europę tworzy, buduje całe narody i ich kulturę. To, że Ewangelia docierała na kontynent $\mathrm{z}$ rozmaitych stron, nie ulegało wątpliwości. Niemniej pluralizacja kultur narodowych rodziła się na fundamencie wspólnotowym aksjologii chrześcijańskiej. Rzecz tkwiła w tym, że mimo podziałów, wartości, których korzeniem była Ewangelia, wraz z uwewnętrznionym dziedzictwem świata antycznego stanowiły spoiwo europejskości - tak w pierwszym, jak i w drugim tysiącleciu.

Jan Paweł II, wskazując wielką wartość czasu „średniowiecza prostej, mocnej i głębokiej wiary; średniowiecza romańskich i gotyckich katedr i wspaniałych sum teologicznych", podkreślał dojrzałość ówczesnej ewangelizacji. Niestety, dramat schizmy wschodniej, nowożytne wpływy reformacji, wojny religijne były pierwszymi zwiastunami tego, co miało nastąpić na przełomie XVII i XVIII wieku. Oświecenie francuskie, angielskie i niemieckie było wyrazem sprzeciwu wobec jedności Europy na fundamencie krzyża i Ewangelii. Prawdziwym „kulturowym dramatem”, jak nazywa to Jan Paweł II, stał się fakt fałszywego przeciwstawiania tych idei chrześcijaństwu, podczas gdy tak naprawdę ich korzeni należy szukać właśnie w nim. Tymczasem szkodliwe nurty oświeceniowe przyczyniają się do rozerwania więzi Europy Zachodniej z chrześcijaństwem, otwierają także drogę wyniszczającemu złu, niszcząc możność osiągnięcia pełni człowieczeństwa. Z punktu widzenia Kościoła bowiem tylko człowiek zaszczepiony w boskości Chrystusa „może się w pełni zrealizować. Odrzucając to zaszczepienie, skazuje się w jakimś sensie na człowieczeństwo niepełne"28. Ten dramat, którego bezpośrednim początkiem była Wielka Rewolucja Francuska, a kontynuacją Wielka Socjalistyczna Rewolucja Październikowa i XX-wieczne totalitaryzmy, złamał pewne tabu,

28 Jan Paweł II, Pamięć i tożsamość, dz. cyt., s. 95-104. 
odebrał człowiekowi czasów nowożytnych, na jego własne życzenie - możność „uczestnictwa w naturze i życiu Boga samego".

Idee odrzucania owego zaszczepienia niestety przetrwały, umacniając się zwłaszcza w środowiskach ateistów i agnostyków. Z tej racji jesteśmy niejako wezwani, jako dziedziczący przesłanie Soboru Watykańskiego II, do stałego dialogu z tymi „posttożsamościowymi” środowiskami. Chodzi tu bowiem o rzecz zasadniczą, centralną - o zbawienie człowieka, narodu, ale i wszystkich narodów i ludów Europy i świata. Niemniej, przy postawie ekumenicznej, wskazanej przez sobór, chodzi tu także o obronę zarówno własnej tożsamości religijnej i narodowej, - jak i o obronę chrześcijańskiej tożsamości Europy. Polska w okresie socjalistycznym mimo opresji zachowała myśl o Bogu jako najwyższym gwarancie wolności człowieka i jego praw. W Europie Zachodniej to przekonanie ulegało stałej erozji. Obecnie coraz bardziej zanika, na co wskazuje także aktualnie obradujący rzymski synod biskupów. W obliczu przemian kulturowo-cywilizacyjnych musimy zatem, chcąc współtworzyć zjednoczoną Europę w oparciu o tajemnicę Krzyża - usilnie walczyć o jej fundament, oparty mocno na chrześcijańskich podstawach. Co więcej, w dalszym ciągu w każdym miejscu i czasie bronić dziedzictwa chrześcijaństwa i kultury polskiej.

Obrona ta nie dokonuje się przeciwko komukolwiek. Przeciwnie, jest wyciągnięciem ręki w stronę tych, którzy nie rozumieją kulturowo-cywilizacyjnego dziedzictwa historii Europy, ludzi poszukujących i ludzi dobrej woli. Jest również zachętą do nieustannej modlitwy za tych, którzy, kierowani złą wolą, dopuszczają się aktów apostazji i aktów bluźnierczych. Rolę naszą w zakresie nowej ewangelizacji należy zatem widzieć podobnie jak rolę soborowego „mesjańskiego ludu”. Tak, jak mieszkańcy Nowej Huty w 1960 roku upominający się o miejsce Krzyża w przestrzeni publicznej, tak i teraz my Polacy - winniśmy, trwając przy wartościach i kulturze narodowej, które nas ukształtowały, broniąc wiary i nie pozwalając na jej bezkarne obrażanie, mające, jak zaznacza Jan Paweł II dość często formę "promocji cywilizacyjnej”, stanowić zaporę przeciwko złu. Wierni wartościom, powinniśmy także z ufnością oczekiwać na owoce współtworzonej przez nas nowej ewangelizacji - nową wiosnę chrześcijaństwa w Polsce, Europie i w świecie. 